\title{
SIMULATION OF INCREMENTAL CONDUCTANCE MPPT WITH DIRECT CONTROL METHOD USING CUK CONVERTER
}

\author{
Amarnath Kurella ${ }^{1}$, R Suresh ${ }^{2}$
}

\begin{abstract}
PV Module Maximum Power Point Tracker (MPPT) is a photovoltaic system that uses the photovoltaic array as a source of electrical power supply. Every photovoltaic $(P V)$ array has an optimum operating point, called the maximum power point, which varies depending on cell temperature, the insulation level and array voltage. The function of MPPT is needed to operate the PV array at its maximum power point. The design of a Maximum Peak Power Tracking (MPPT) is proposed utilizing a cuk converter topology. Solar panel voltage and current are continuously monitored by a MPPT, and the duty cycle of the cuk converter continuously adjusted to extract maximum power. The design consists of a PV array, DC-DC cuk converter and many such algorithms have been proposed. However, one particular algorithm, the Incremental Conductance method, claimed by many in the literature to be inferior to others, continues to be by far the most widely used method in commercial PV MPPT's. The general model was implemented on Mat lab, and accepts irradiance and temperature as variable parameters and outputs the I-V characteristic and P-V characteristic
\end{abstract}

Index Terms: PV system; Maximum power point tracking (MPPT); Incremental conductance (Inccond); digital signal processor $(d s p)$

\section{INTRODUCTION}

Unfortunately, PV generation systems have two major problems: the conversion efficiency of electric power generation is very low $(9-16 \%)$, especially under low irradiation conditions and the amount of electric power generated by solar arrays changes continuously with weather conditions. Moreover, the solar cell V-I characteristic is nonlinear and changes with irradiation and temperature. In general, there is a point on the V-I or V-P curve only, called the Maximum Power Point (MPP), at which the entire PV system operates with maximum efficiency and produces its maximum output power [5]. The location of the MPP is not known, but can be located, either through calculation models or by search algorithms. Maximum Power Point Tracking (MPPT) techniques [6] are used to maintain the PV array's operating point at its MPP. MPPT is not a mechanical tracking system that "physically moves" the modules to make them point more directly at the sun. MPPT is a fully electronic system that varies the electrical operating point of the modules so that the modules are able to deliver maximum available power.

As the MPP is always requested, and this point can be found in any position on $\mathrm{I}-\mathrm{V}$ curve, depending on temperature and irradiation levels, the natural DC-DC converters [25] to be applied as MPP Trackers are Buck, Boost, Buck-Boost, and Cuk converter.
Safari A., Mekhilef S[1] presented a paper about that The basic structural unit of a solar module is the PV cells and PV module characteristics are comprehensively discussed, which indicates an exponential and non-linear relation between output current and voltage of PV module. It gives an idea about the significant points on each I-V curve: open circuit voltage, short circuit current and the operating point where the module performs the maximum power (MPP).

ROBERTO FARANDA, SONIA LEVA [6] discussed Many MPPT techniques under the energy production point of view: Constant Voltage Method, Short-Current Pulse Method, Open Voltage Method, Perturb and Observe Method, Incremental Conductance Method and Temperature Method .These techniques vary between them in many aspects, including simplicity, convergence speed, hardware implementation, sensors required, cost, range of effectiveness and need for parameterization.

N.Femia, G.Petrone, G.Spagnuolo, M.Vitelli [10] discussed how the Maximum power point tracking (MPPT) techniques are used in photovoltaic (PV) systems to maximize the PV array output power by tracking continuously the maximum power point (MPP) which depends on panels temperature and on irradiance conditions. The issue of MPPT has been addressed in different ways in the paper.

E. Durán, M. Sidrach-de-Cardona, J. Galán, and J.M. Andújar [25] are discussed several topologies of DC-DC converters for 
measuring the characteristic curves of photovoltaic (PV) modules is theoretically analyzed. Eight topologies of DC-DC converters with step-down/step-up conversion relation BuckBoost single inductor, CSC (Canonical Switching Cell), Cuk, SEPIC (Single-Ended Primary Inductance Converter), Zeta, Fly back, Boost-Buck-Cascaded, and Buck-Boost-Cascaded converters) are compared and evaluated

\section{WORKING}

Working of a PV cell is based on the basic principle of photoelectric effect. Photoelectric effect can be defined as a phenomenon in which an electron gets ejected from the conduction band as a consequence of the absorption of sunlight of a certain wavelength by the matter (metallic or nonmetallic solids, liquids or gases).So, in a photovoltaic cell, when sunlight strikes its surface, some portion of the solar energy is absorbed in the semiconductor material. If absorbed energy is greater than the band gap energy of the semiconductor, the electron from valence band jumps to the conduction band. By this, pairs of hole-electrons are created in the illuminated region of the semiconductor.

The electrons thus created in the conduction band are now free to move. These free electrons are forced to move in a particular direction by the action of electric field present in the PV cells. These flowing electrons constitutes current and can be drawn for external use by connecting a metal plate on top and bottom of PV cell. This current and the voltage (created because of its built-in electric fields) produces required power.

A maximum power point tracker (MPPT) is a high efficiency DC to DC converter which functions as an optimal electrical load for a photovoltaic (PV) cell, most commonly for a solar panel or array, and converts the power to a voltage or current level which is more suitable to whatever load the system is designed to drive.

PV cells have a single operating point where the values of the current (I) and Voltage (V) of the cell result in a maximum power output. Maximum power point trackers utilize some type of control circuit or logic and algorithm to search for this point and thus to allow the converter circuit to extract the maximum power available from a cell. In short, photovoltaic (PV) arrays are used to provide energy and MPPT are used to correct the variations in the current-voltage characteristics of the solar cells. The point on the current-voltage (I-V) curve of a solar module under illumination, where the product of current and voltage is maximum (Pmax, measured in watts).

The points on the I and $\mathrm{V}$ scales which describe this curve point are named Imp (current at maximum power) and Vmp (voltage at maximum power.). For the array to be able to delivered the maximum possible amount of power, either the operating voltage or current needs to be carefully controlled
Fig. 1 is illustrating the block diagram of MPPT system with direct control using cuk converter. In this chapter explain the mathematical model of PV system with comparative study of MPPT methods.

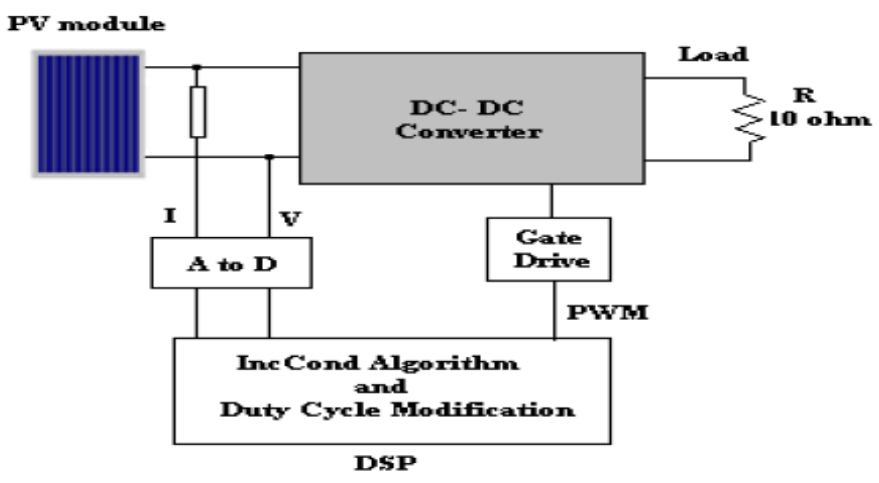

Fig.1 Direct control method used in MPPT

\subsection{PV Cell}

Fig.2 shows the equivalent circuit of the ideal photovoltaic module. The basic equation for output current of module[1] is

$$
I=n_{p} I_{p h}-n_{p} I_{r g}\left[\exp \left(k_{o} \frac{v}{n_{g}}\right)-1\right]
$$

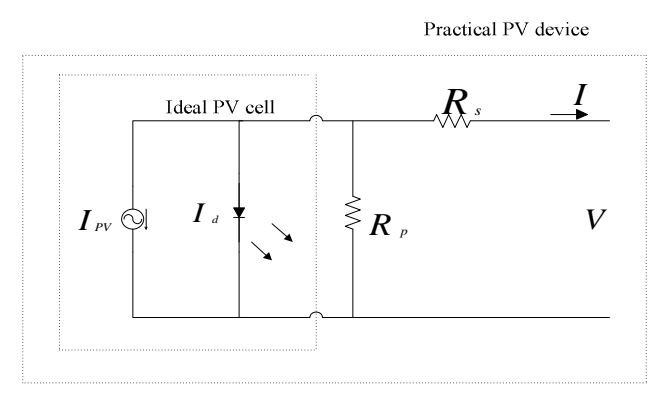

Fig.2 Single-diode model of the theoretical photovoltaic cell and equivalent circuit of a practical photovoltaic device including the series and parallel resistances

Where I is the PV array output current, V is the PV output voltage, $\mathbb{I}_{\mathrm{ph}}$ is the cell photocurrent that is proportional to solar irradiation, $n_{s}$ represents the number of PV cells Connected in series and $n_{p}$ represents the number of such strings connected in parallel.

$$
I_{p h}=\left[I_{s o r}+k_{i}\left(T-T_{r}\right) \frac{z}{100}\right.
$$


$I_{s e r}$ is the cell short-circuit current at reference temperature and radiation,

$k_{i}$ is short circuit current temperature coefficient,

$\mathrm{T}$ is the Nominal Temperature i.e 295.15K (25C)

$T_{r}$ is the cell reference temperature,

$\mathrm{S}$ is solar irradiation in $\frac{w}{\mathrm{~cm}^{2}}$

$I_{\mathrm{rs}}$ is the cell reverse saturation current that mainly depends on the temperature, $\mathrm{K}$ is a constant.

$$
I_{r g}=I_{r r}\left[\frac{T}{T_{r}}\right]^{3} \exp \left(\frac{q E_{G}}{k A}\left[\frac{1}{T_{r}}-\frac{1}{T}\right]\right)
$$

$I_{r r}$ is the reverse saturation at $T_{r}$

$E_{G}$ is the band-gap energy of the semiconductor used in the cell.

A is the area of photovoltaic cell.

$\mathrm{k}$ is Bolttzmann constant i.e. 1.3806503*10-23jouls/kelvin

$\mathrm{q}$ is electron charge i.e. $1.607 * 10-19 \mathrm{c}$

These techniques vary in many aspects as: simplicity, convergence speed, digital or analogical implementation, sensors required, cost, range of effectiveness, and in other aspects [6] [7].

\subsection{Characteristics of Py Cell}

The performance characteristics of a photovoltaic module depend on its basic materials, Manufacturing technology and operating conditions.

Three points in these curves are of particular interest:

1. Short circuit point, where the voltage over the module is zero and the current is at its Maximum (short circuit current Isc).

2. Maximum power point or MPP, where the product of current and voltage has its maximum (defined by Impp.Vmpp).

3. Open circuit point, where the current is zero and the voltage has its maximum (open circuit voltage Voc).

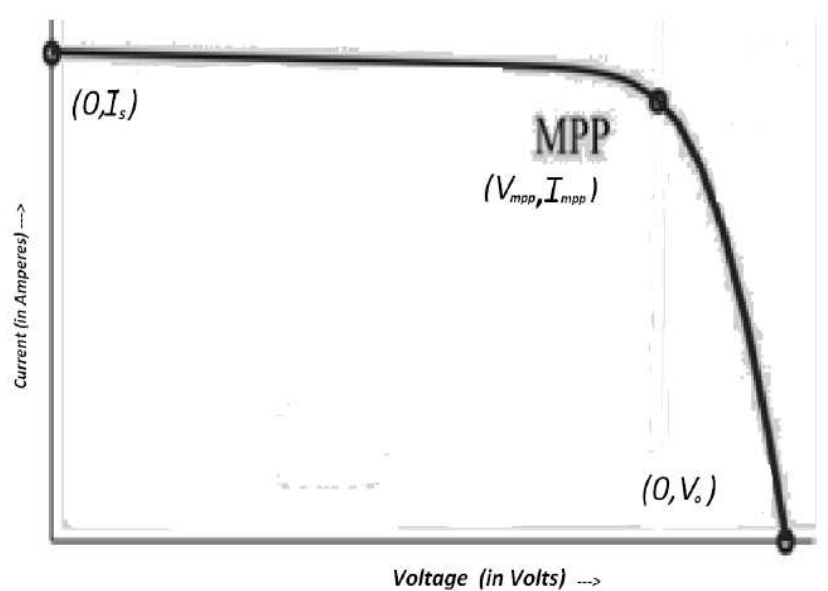

Fig.3 PVA Characteristics V (X axis) Vs I (Y axis)

The measurements taken for obtaining an I-V curve is done by controlling the load current. At open circuit, when no load current is generated, a first characteristic value can be measured: the open circuit voltage Voc. Increasing the load fed by the photovoltaic module leads to a decreasing voltage $\mathrm{V}$ with an increasing current I. In other words, by increasing the load current from zero to its maximum value, the operating point moves from the open circuit voltage at zero current to the short circuit current Isc at zero voltage. The series of all measured pairs $(\mathrm{V}, \mathrm{I})$ yields the characteristic I-V curve of the module. From the characteristic curve of the module, it is clear that the open circuit voltage of the photovoltaic module, the point of intersection of the curve with the horizontal axis, varies little with solar radiation changes. It is inversely proportional to temperature, i.e., a rise in temperature produces a decrease in voltage. Short circuit current, the point of intersection of the curve with the vertical axis, is directly proportional to solar radiation and is relatively steady with temperature variations. Actually, the photovoltaic module acts like a constant current source for most parts of its I-V curve [3]

As demonstrated in Fig.4, Fig.5, an increase in solar radiation causes the output current to increase and the horizontal part of the curve moves upward. An increase in cell temperature causes the voltage to move leftward, while decreasing temperature produces the opposite effect. Thus, the I-V curves display how a photovoltaic module responds to all possible loads under different solar radiation and cell temperature conditions. 


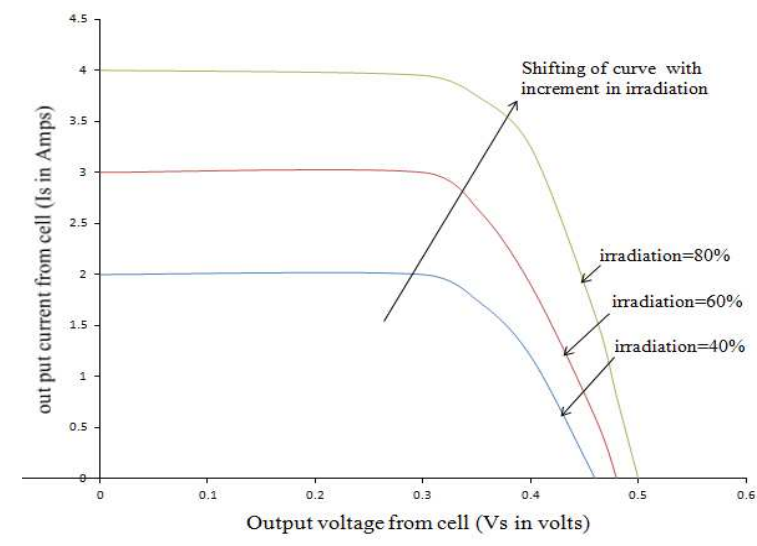

Fig.4 Voltage Vs Current characteristics of PVA with Variation of Insulation

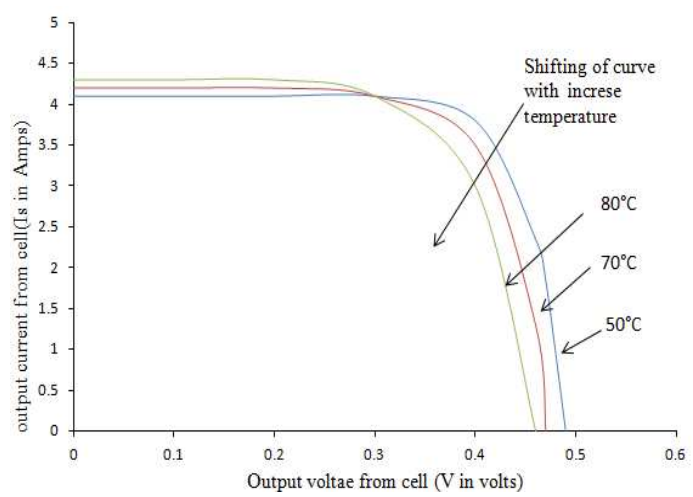

Fig.5 Characteristics of PVA incorporating effect of Temperature

Photovoltaic modules have a very low conversion efficiency of around $15 \%$ for the manufactured ones. Besides, due to the temperature, radiation and load variations, this efficiency can be highly reduced. In fact, the efficiency of any semiconductor device drops steeply with the temperature. In order to ensure that the photovoltaic modules always act supplying the maximum power as possible and dictated by ambient operating conditions, a specific circuit known as Maximum Power Point Tracker (MPPT) is employed.

In most common applications, the MPPT is a DC-DC converter controlled through a strategy that allows imposing the photovoltaic module operation point on the Maximum Power Point (MPP) or close to it. On the literature, many studies describing techniques to improve MPP algorithms were published [9] [10], permitting more velocity and precision of tracking. On the other hand, there is no a theory to guide the designer to choose, among the DC-DC converters family, the best one to operate as MPPT, thus, in most cases, the designers are tempted to use the simplest DC-DC converters[25]

\subsection{Perturb and Observe MPPT Method}

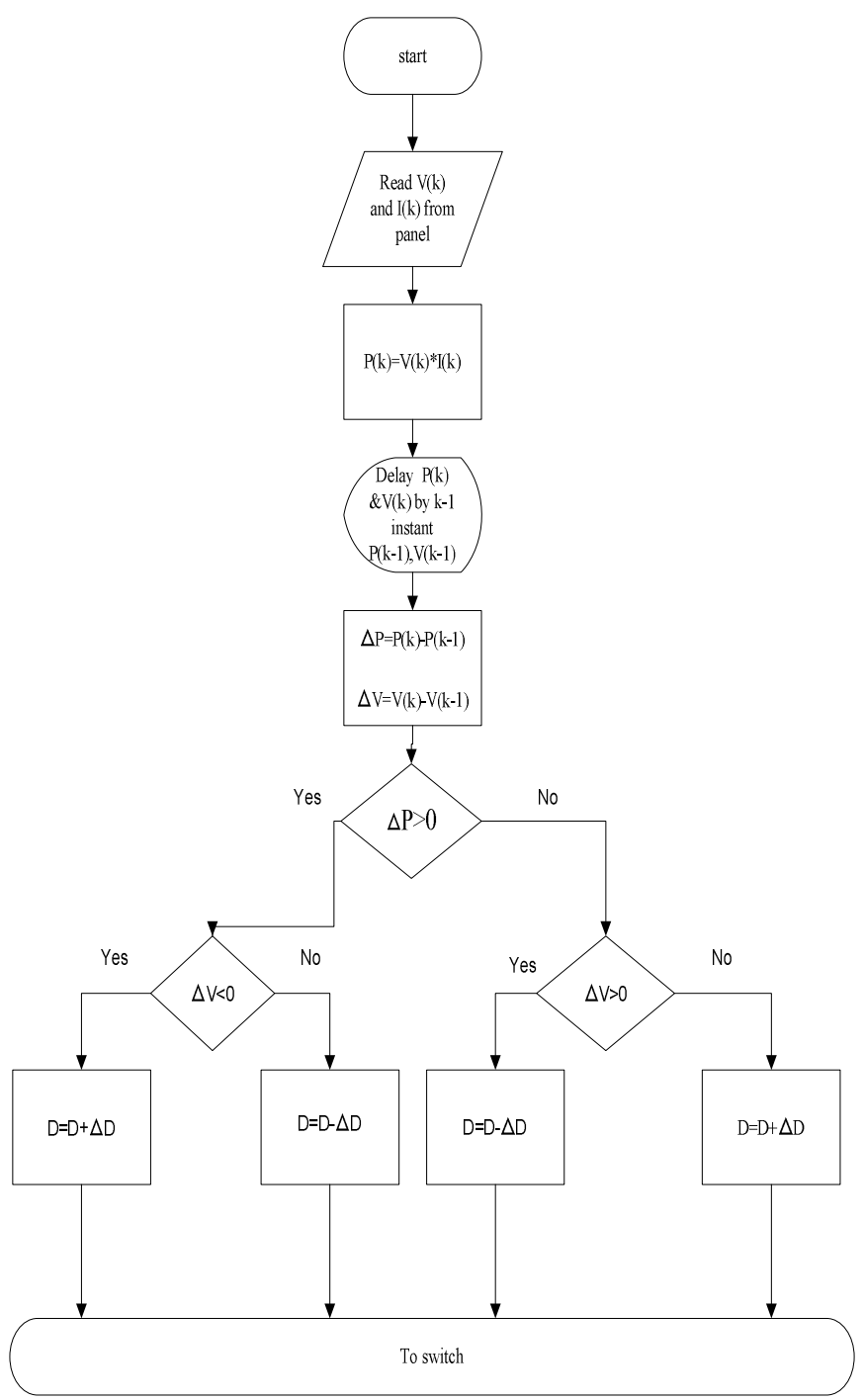

Fig.7 Flowchart of Perturb and Observe $(\mathrm{P} \& \mathrm{O})$ methods

The Perturb and Observe algorithm[6-8] operate by periodically perturbing(i.e. incrementing or decrem enting)the array terminal voltage or current and comparing the PV output power with that of the previous perturbation cycle. If the PV array operating voltage changes and power increases, the control system moves the PV array operating point in that direction; otherwise the operating point is moved in the opposite direction. In the next perturbation cycle the algorithm continues in the same way.The flow chart of the Perurb and Observe algorithm shown in Fig.7.

\subsection{Incremental Conductance Algorithm}

The purpose of the The Incremental Conductance method[610] offers good performance under rapidly changing 
atmospheric conditions. Fig. 8 shows that the slope of the PV array power curve is zero at the MPP, increasing on the left of the MPP and decreasing on the right hand side of MPP.The basic equations of this method are as follows[1]

$$
\begin{aligned}
& \frac{d I}{d V}=-\frac{I}{V} \text { AtMPP } \\
& \frac{d I}{d V}>-\frac{I}{V} \quad \text { LeftofMPP } \\
& \frac{d I}{d V}<-\frac{I}{V} \text { Right of MPP }
\end{aligned}
$$

Where I and V are PV array output current and voltage respectively The left hand side of equations represents Incremental conductance of PV module and the right hand side represents the instantaneous conductance. From (2), (3) and (4) it is obvious that when the ratio of change in the output conductance is equal to the negative output conductance, solar array will operate at the maximum power point.

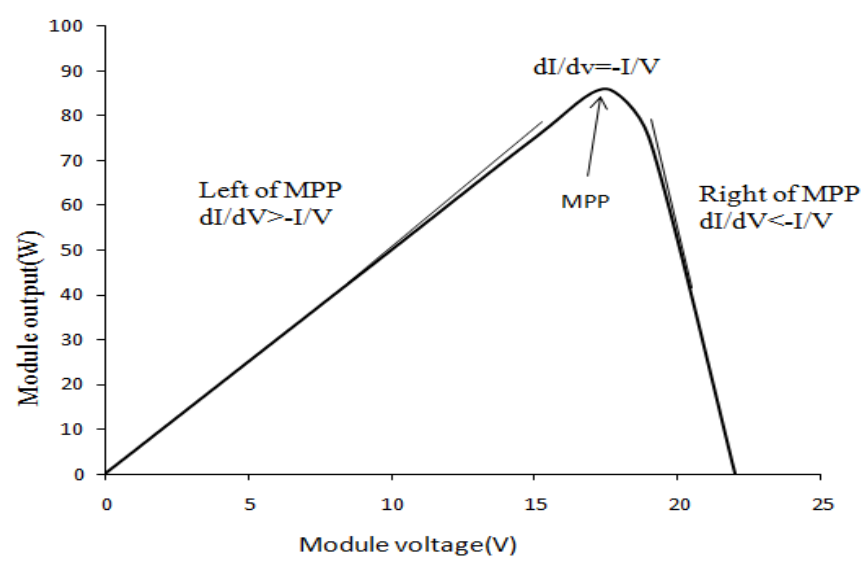

Fig.8 Basic idea of incremental conductance method on a P-V curve of a solar module

In other words, by comparing the conductance at each sampling time, the MPPT will track the maximum power of the PV module[12] [13]. The flow chart of Incremental Conductance method shown in Fig.9.It makes use of instantaneous and incremental conductance to generate an error signal which is zero at MPP; however it is not zero at most of the operating points, but it make the error from the MPPs near to zero [3]

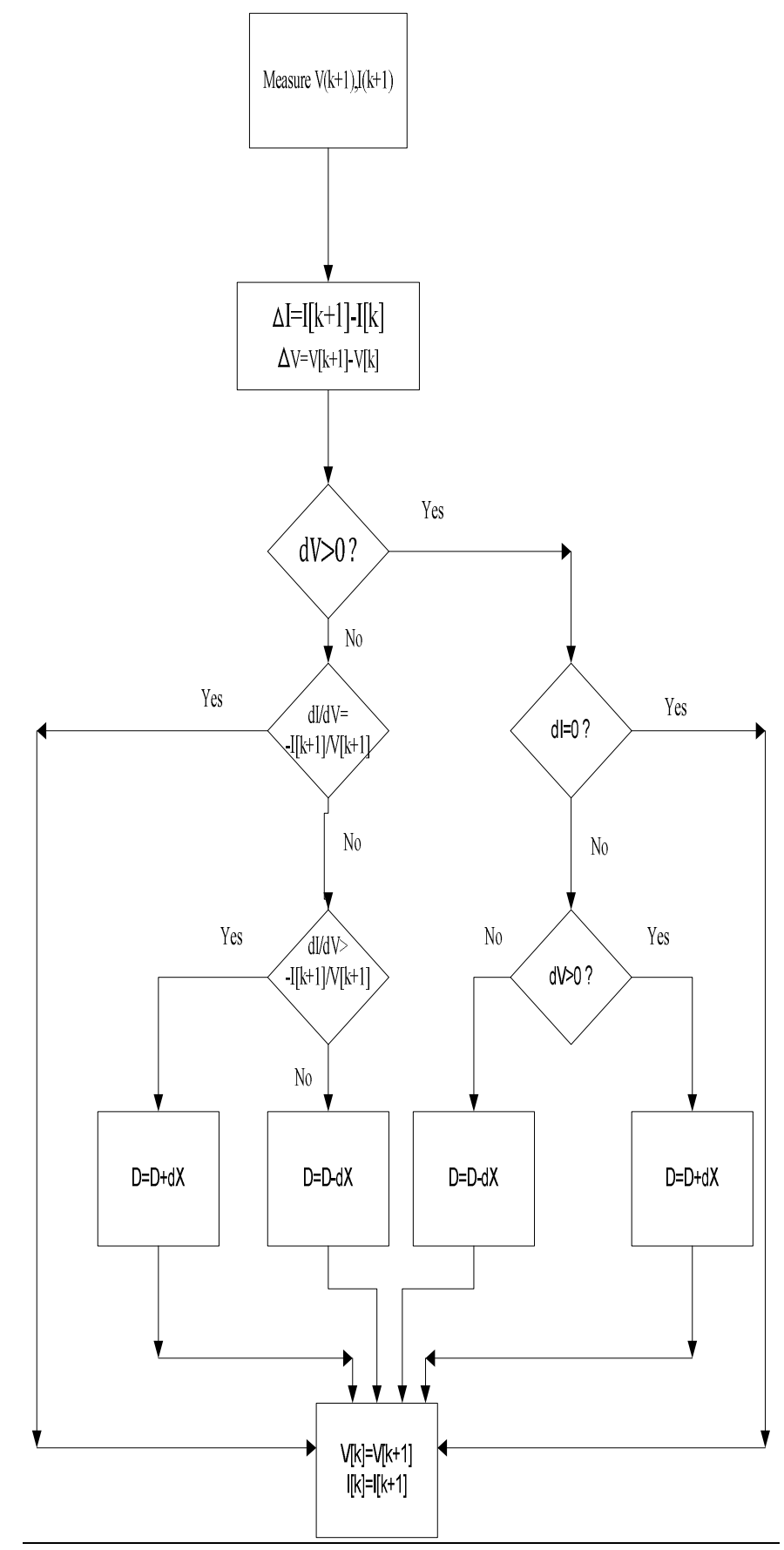

Fig.9 Flowchart of Incremental conductance method

\subsection{Comparison}

A common problem in Pertub and Observe algorithm[9] is that the array terminal voltage is perturbed every MPPT cycle; therefore when the MPP is reached, the output power oscillates around the maximum, resulting in power loss in the PV system. This is especially true in constant or slowly-varying 
atmospheric conditions. Furthermore, Perturb and Observe method can fail under rapidly changing atmospheric conditions.

Incremental conductance method [5-8] is more efficient than Perturb Observe method [5-7] because panel terminal voltage is changed according to its value relative to the maximum power point voltage. Therefore, this method is independent on solar panel characteristics.

Table .1 Overall MPP Tracking Efficiencies

\begin{tabular}{|l|l|l|l|l|}
\hline \multirow{2}{*}{$\begin{array}{l}\text { Sky } \\
\text { conditions }\end{array}$} & \multicolumn{2}{|l|}{ Perturb and observe } & \multicolumn{2}{l|}{$\begin{array}{l}\text { Incremental } \\
\text { conductance }\end{array}$} \\
\cline { 2 - 5 } & $\begin{array}{l}\text { Days } \\
\text { of data }\end{array}$ & $\begin{array}{l}\text { MPPTeffi } \\
\text { ciency }\end{array}$ & $\begin{array}{l}\text { Days of } \\
\text { data }\end{array}$ & $\begin{array}{l}\text { MPPT } \\
\text { efficienc } \\
\text { y }\end{array}$ \\
\hline clear & 20 & 98.7 & 17 & 98.7 \\
\hline $\begin{array}{l}\text { Partly } \\
\text { cloudy }\end{array}$ & 14 & 96.5 & 11 & 97 \\
\hline $\begin{array}{l}\text { cloudy } \\
\text { Over all }\end{array}$ & 93 & 98.1 & 11 & 96.7 \\
\hline $\begin{array}{l}\text { Simulate } \\
\text { over all }\end{array}$ & 99.3 & 39 & 97.4 \\
\hline
\end{tabular}

Incremental conductance method eliminates the problem that is seen in Perturb and Observe method. Therefore, oscillations that cause power loss are not occurred in Incremental conductance method. A summary of the MPPT efficiencies of two algorithms are shown in Table 1, Table. 2.

To complete our analysis a simple discussion about the cost of the MPPT technique is presented [2] [3]. A satisfactory MPPT costs comparison can be carried out by knowing the technique (analogical or digital) adopted in the control device, the number of sensors, and the use of additional power component, considering the other costs (power components, electronic components, boards, etc...) equal for all the devices. To make all the cost comparable between them, the computation cost comparison is formulated taking into account the present spread of MPPT methods. The number of sensors required to implement the MPPT technique also affects the final costs. Most of the time, it is easier and more reliable to measure voltage than current and the current sensors are usually more expensive and bulky. The irradiance or temperature sensors are very expensive and uneconomic.
Table 2: Comparison of MPPT methods

\begin{tabular}{|c|c|c|}
\hline Specifications & $\begin{array}{l}\text { Perturb and } \\
\text { Observe }\end{array}$ & $\begin{array}{l}\text { Incremental } \\
\text { Conductance }\end{array}$ \\
\hline Efficiency & \begin{tabular}{l}
\multicolumn{2}{c}{ Medium } \\
About $95 \%$ \\
depending on how \\
method \\
optimized
\end{tabular} & $\begin{array}{l}\text { High About } 98 \% \\
\text { depending on how } \\
\text { method is } \\
\text { optimized }\end{array}$ \\
\hline Complexity & & Difficult \\
\hline Realization & $\begin{array}{l}\text { Easy to implement } \\
\text { as few measured } \\
\text { parameters }\end{array}$ & $\begin{array}{l}\text { More complex } \\
\text { hence Micro } \\
\text { controller/DSP } \\
\text { needed }\end{array}$ \\
\hline Cost & Relatively lower & $\begin{array}{l}\text { Involves higher } \\
\text { cost }\end{array}$ \\
\hline Reliability & $\begin{array}{l}\text { Not very accurate } \\
\text { and difficult to } \\
\text { whether operating } \\
\text { at MPPT or not }\end{array}$ & $\begin{array}{l}\text { Accurate and } \\
\text { operates at MPPT } \\
\text { but response time } \\
\text { dependent }\end{array}$ \\
\hline $\begin{array}{l}\text { Rapid changing } \\
\text { atmospheric } \\
\text { conditions(varying } \\
\text { radiation and } \\
\text { temp) }\end{array}$ & $\begin{array}{l}\text { Unpredictable } \\
\text { performance with } \\
\text { Oscillations around } \\
\text { MPP, slower } \\
\text { response }\end{array}$ & $\begin{array}{lr}\text { Good } & \text { and } \\
\text { automatically } & \\
\text { adjust } & \text { module } \\
\text { operating } & \text { voltage } \\
\text { with } & \text { no } \\
\text { oscillations } & \end{array}$ \\
\hline Other Limitations & $\begin{array}{l}\text { Difficult to locate } \\
\text { MPP }\end{array}$ & $\begin{array}{l}\text { Voltage and } \\
\text { current sensors are } \\
\text { need usually high } \\
\text { expensive }\end{array}$ \\
\hline
\end{tabular}

\section{CONVERTER CONFIGURATIONAND}

\section{SELECTION}

Solar cells are the fundamental power conversion unit of a photovoltaic (PV) system. The basic operation of a solar cell is characterized by its I-V curve. Only the experimental measurement of the I-V curve allows us to know with precision the electrical parameters of a PV cell, module or array. This measure provides important information for the design, installation and maintenance of photovoltaic systems. The experimental measure of the I-V characteristic curve can be performed using step-up/step-down DC-DC converters in Continuous Conduction Mode (CCM) [1]. The switching power of DC-DC converters are widely used in photovoltaic systems to transform DC power from a voltage level to another, and for tracking the maximum power point (MPPT).In this chapter, a survey of step-down/step-up DC-DC converters and their application to obtain I-V characteristic curves of PV modules is presented 


\subsection{Choice of Converter for MPPT}

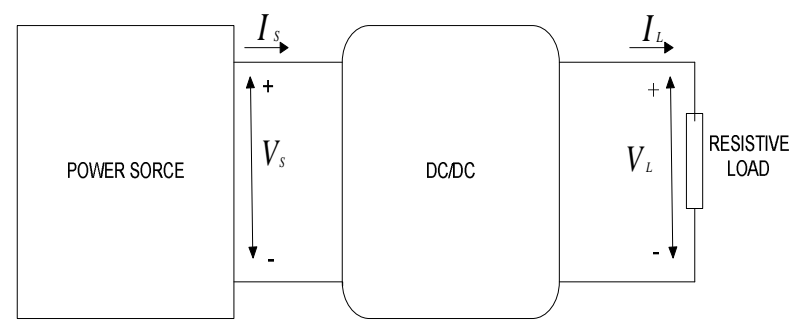

Fig.10 Converter acting as a Maximum Power Point Tracker

When proposing a maximum power point tracker, the major job is to choose and design a high efficient converter which is supposed to operate as the main part of the MPPT. The choosing of DC-DC converter based on the desired output voltage from the MPPT in term to ensure the PV module will operate at the maximum point.

\subsection{CUK CONVERTER}

The load voltage of converter can be obtained in terms of load current by the relation

$$
V_{\text {load }}=I_{\text {load }} R_{\text {load }}
$$

Where $\mathrm{V}_{\text {load }}$ is the load voltage, $\mathrm{I}_{\text {load }}$ is the load current and $\mathrm{R}_{\text {load }}$ is the load resistance. We shall assume the operation of a cuk converter

$$
V_{\text {load }}=\frac{\mathrm{D}}{1-\mathrm{D}} V_{\text {modula }}
$$

The average input power to the DC-DC converter equals the average output power thereby, we get a relation

$$
I_{\text {load }}=\frac{1-D}{D} I_{\text {module }}
$$

Combining the above two equations, we write

$$
\frac{V_{\text {module }}}{I_{\text {madule }}}=\frac{(1-\mathrm{D})^{2}}{\mathrm{D}} \mathrm{R}_{\text {load }}
$$

$\mathrm{D}$ here represents the voltage conversion ratio of the cuk converter. So, when seen from the source side, the effective

$$
\left(\frac{1-\mathrm{D}}{\mathrm{D}}\right)^{2} \mathrm{R}_{\mathrm{load}}
$$

resistance will be

. This is a function of $\mathrm{D}$, which we can control to fix the operating point near the MPP. We have to note that the range of D is zero to one. The MPP can be found in any position on I-V curve, depending on temperature and radiation levels, the natural DC-DC converters to be applied as MPP Trackers are Buck-Boost, Cuk, because they have no non-operational region. TABLE.3 summarizes the equations for DC-DC Buck, Boost, Cuk, converters. Comparative study on different schemes of switching converters is presented in the chapter.

\begin{tabular}{|l|l|l|}
\hline $\begin{array}{l}\text { DC-DC } \\
\text { converter }\end{array}$ & $\mathbf{R}_{\mathrm{e}}\left(\mathbf{D}, \mathbf{R}_{\text {load }}\right)$ & \multicolumn{1}{c|}{} \\
Range
\end{tabular}

The need of converter in the MPPT system is to maximize the varied input of DC voltage. In term of maximized the output voltage by step up or step down the input voltage the cuk converter is ideally to be choose in the MPPT design compared to the Buck converter, Boost converter because cuk converter has low switching losses and highest efficiency among non-isolated DC-DC converters [26-30]. It also can provide a better input and output current characteristic due to the inductor on the both input and output stage. The maximum power point of $12 \mathrm{~V}$ commercial PV module is above or below that voltage for most combinations of insolation and temperature. So buck and boost converter can operate at the MPP undermost step up and step down the voltage but not at all condition. While for the cuk converter output voltage must be above or below the input voltage so that's why, cuk converter will always be able to operate at the panel's MPP. In term of simplicity a buck converter with a MOSFET switch still requires an additional diode or MOSFET's to block the reverse current flow when the panel voltage drops below the battery voltage, as an advantages of cuk converter naturally it has this devices as part of its structure, which eliminates an additional source of voltage drop and power loss. A boost converter has been employed in this application to regulate the power output to the load. It consists of an inductor, a logic level, Power MOSFET switch, a ordinary diode and capacitors. Fig. 11 shows a typical connection of a cuk converter. The basic converter containing at least two semiconductors switches (a diode and a transistor). Filters made of capacitors (sometimes in combination with inductors) 
are normally added to the output of the converter to reduce output voltage ripple.

\subsection{Operation of Cuk Converter}

Figs.12a and 12b depicts cuk converter and its operating modes which used as the power stage interface between PV module and the load. Cuk converter has two modes of operation. First mode of operation is when the switch is closed (ON) and it is conducting as a short circuit. In this mode, capacitor releases energy to the output. The equations for the switch conduction mode are as follows

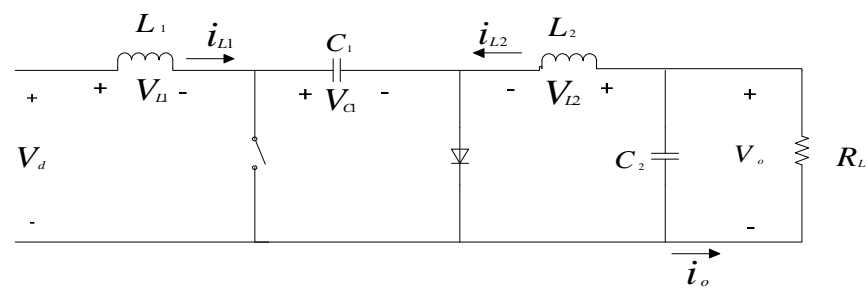

Fig.11 Cuk converter
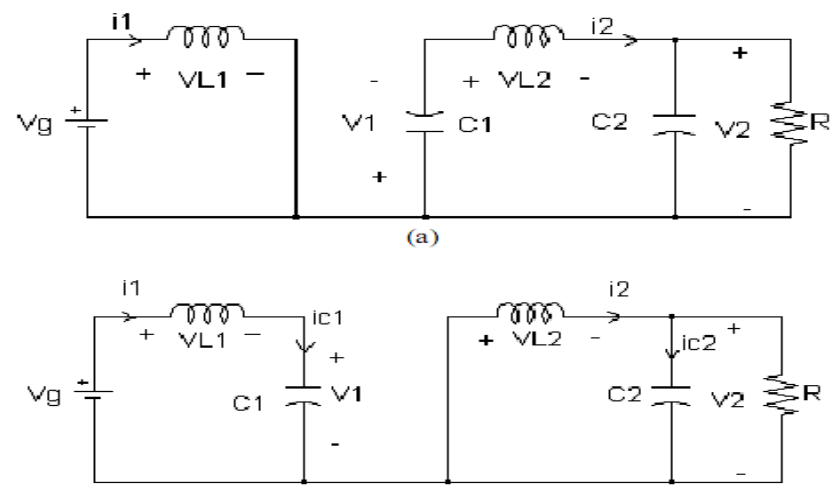

(b)

Fig.12 Cuk converter with (a) switch ON and (b) switch OFF

$$
\begin{aligned}
& v_{L_{1}}=V_{g} \\
& v_{L 2}=-v_{1}-v_{2} \\
& i_{G 1}=i_{2} \\
& i_{G 2}=i_{2}-\frac{v_{2}}{R}
\end{aligned}
$$

On the second operating mode when the switch is open (OFF), diode is forward biased and conducting energy to the output. Capacitor $\mathrm{C} 1$ is charging from input. Equations for this mode of operation are:

$$
\begin{aligned}
& v_{L 1}=V_{g}-v_{1} \\
& v_{L 2}=-v_{2} \\
& i_{a 1}=i_{1} \\
& i_{a 2}=i_{2}-\frac{v_{2}}{R}
\end{aligned}
$$

The principles of cuk converter operating conditions state that the average values of the periodic inductor voltage and capacitor current waveforms are zero, when the converter operates in steady state. Some analysis of cuk converter specifications is provided in [25]. The power circuit of the proposed system consists of a Cuk converter and gate drive, the control of the switching is done using the control circuit. The control tasks involve measuring analog voltage and current of the PV module using current and voltage sensors, convert them to digital using ADC, process the obtained information in a microcontroller and then compare to the predefined values to determine the next step, revert the PWM to the gate drive and hence control the switching of IGBTs. The control loop frequently happens with respect to the sampling time and the main program continues to track the MPPs.

The cuk converters provide the opportunity to have either higher or lower output voltage compare with input voltage. Although buck and boost configuration is cheaper than cuk, some disadvantages such as discontinuous input current, high peak currents in power components and poor transient response makes it less efficient. On the other hand, cuk converter has low switching losses and highest efficiency among non-isolated DC-DC converters [26]. It also can provide a better input and output current characteristic due to the inductor on the both input and output stage.

\section{SIMULATION RESULTS}

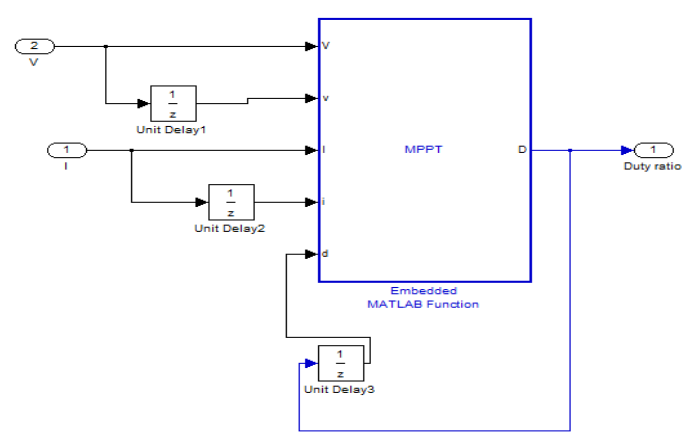

Fig.13 Simulink model of Incremental Conductance MPPT 


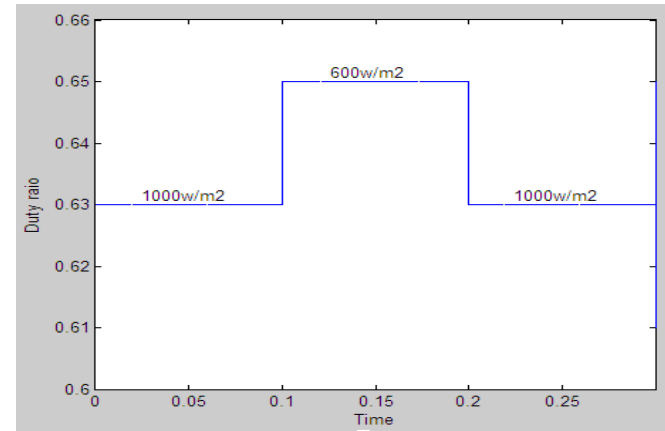

Fig.14 Change in Duty ratio with irradiation

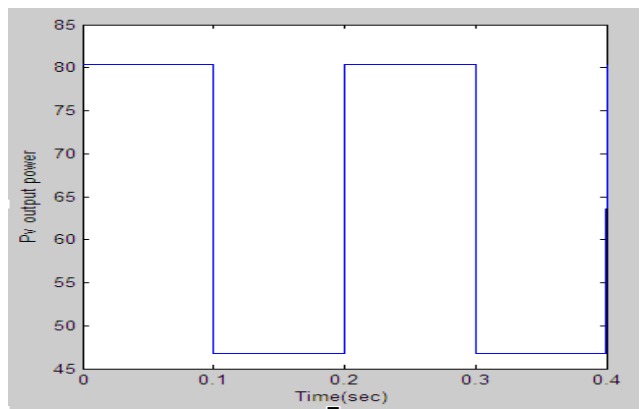

Fig.15 PV output power changing with Irradiation

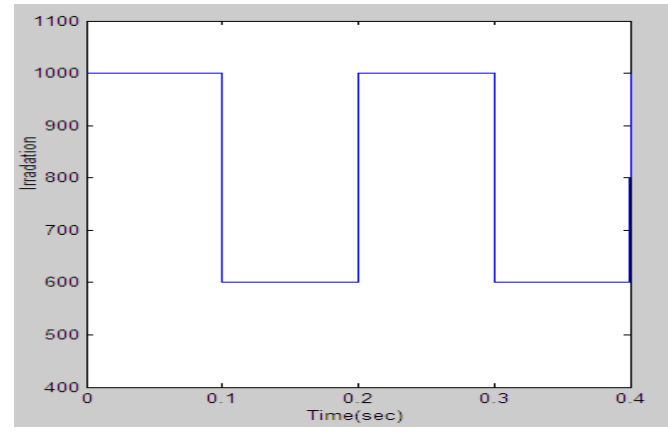

Fig.16 changing irradiation with Time (sec)

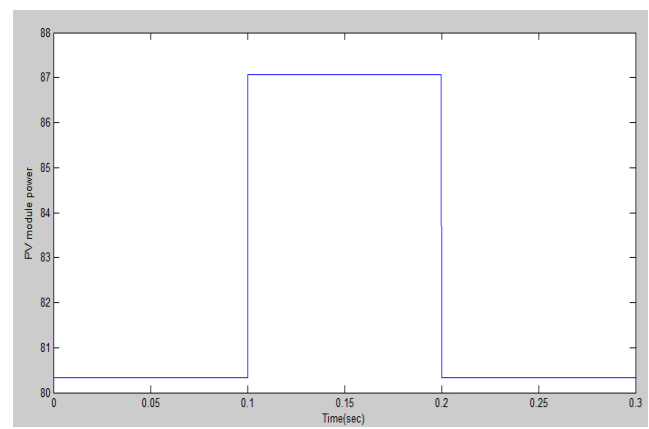

Fig. 17 PV module output Power changing with Temperature

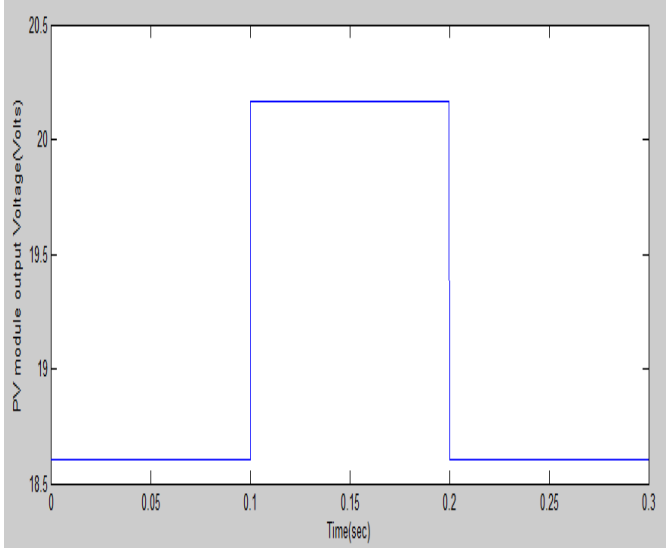

Fig. 18 PV module output Voltage

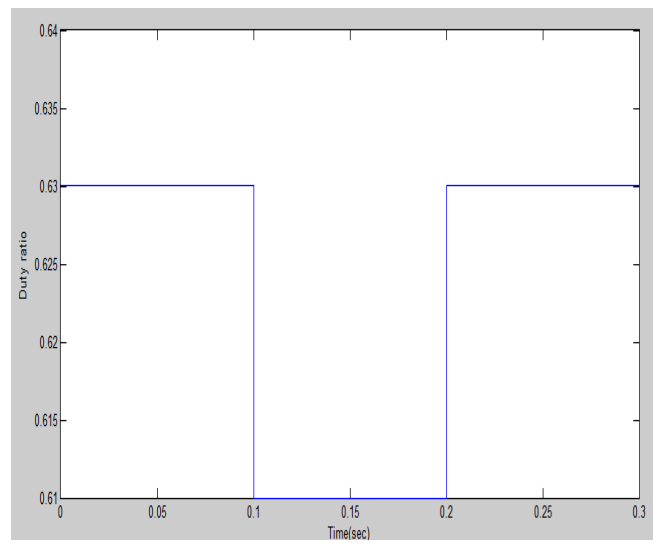

Fig. 19 Change in Duty ratio with Temperature

\section{CONCLUSIONS}

From the observations made above, we conclude that the system developed is capable of extracting maximum power from the photovoltaic module at the same time providing a regulated DC supply. The proposed PV system and MPPT was simulated. The Incremental Conductance method is more efficient compare to all MPPT methods because panel terminal voltage is changed according to its value relative to the MPP voltage. The Incremental Conductance method is more efficient than Perturb and Observe method because panel terminal voltage is changed according to its value relative to the MPP voltage. The Incremental Conductance method offers good performance under rapidly changing atmospheric conditions. On the other hand; cuk converter has low switching losses and highest efficiency among non-isolated DC-DC converters. It also provides a better input and output current characteristic due to the inductor on both input and output stage. Thus cuk converter configuration is a proper choice to be employed in designing the MPPT. 


\section{REFERENCES}

[1] Safari A, Mekhilef S, "Simulation and Hardware Implementation of Incremental Conductance MPPT with Direct Control Method Using Cuk Converter", IEEE Trans, March 2010.

[2] Abou El-Maaty Metwally Metwally Aly Abd El-Aal, "Modeling and Simulation of a Photovoltaic Fuel Cell Hybrid System", Dissertation for Dr.-Ing, University of Kassel,Germany, 15 April 2005.

[3] H.S.Rauschenbach. "Solar cell array design handbook", Van Nostrand Reinhold, 1980.

[4] H. J. M“oller, "Semiconductors for Solar Cells". Norwood, MA: Artech House, 1993.

[5] V. Salas, E. Olias, A. Barrado, and A. Lazaro, "Review of the maximum power point tracking algorithms for stand-alone photovoltaic systems", Sol. Energy Mater. Sol. Cells, vol. 90, no. 11, pp. 1555-1578, Jul. 2006.

[7] L. Pang, H. Wang, Y. Li, J. Wang, and Z. Wang, "Analysis of Photovoltaic Charging System Based on MPPT", Proceedings of Pacific-Asia Workshop on Computational Intelligence and Industrial Application 2008 (PACIIA '08), Dec 2008, pp. 498-501.

[8] K.S.R. Rajeswararao, S. UmaShankar, N. Sudhakar, D.Vijaya Kumar, "Performance of a Controlled Capacitor Charging type converter Based on Switch Utilization Ratio", International conference on Advances in Renewable Energy(ICARE 2010), Maulana Azad National Institute of Technology, Bhopal,June 24-26, 2010.

[9] A. S. Sedra and K. C. Smith, Microelectronic Circuits. London, U.K.: Oxford Univ. Press, 2006.

[10] Trishan Esram, Patrick L. Chapman, "Comparison of Photovoltaic Array Maximum Power Point Tracking Techniques", IEEE Trans. on Energy Conversion, vol. 22, no. 2, pp.439-449, June 2007

[11] H.S.Rauschenbach. "Solar cell array design handbook", Van Nostrand Reinhold, 1980.

[12] Trishan Esram, Patrick L. Chapman, "Comparison of Photovoltaic Array Maximum Power Point Tracking Techniques", IEEE Trans. on Energy Conversion, vol. 22, no. 2, pp.439-449, June 2007.

[13] Zhou Yan, Liu Fei, Yin Jinjun, Duan Shanxu, "Study on realizing MPPT by improved incremental conductance method with variable step-size", ICIEA, IEEE Conference on Industrial Electronics and applications, pp. 547 550, June 2008.

[14 N.Femia, D.Granozio, G.Petrone, G.Spaguuolo, M.Vitelli, "Optimized One-Cycle Control in Photovoltaic Grid Connected Applications", IEEE Trans. Aerosp. Electron.Syst, vol. 2, no 3, July 2006.

[15] W. Wu, N. Pongratananukul, W. Qiu, K. Rustom, T. Kasparis and I. Batarseh, "DSP-based Multiple Peack Power Tracking for Expandable Power System”, Proc. APEC, 2003, pp. 525-530.
[16] C. Hua and C. Shen, "Comparative Study of Peak Power Tracking Techniques for Solar Storage System", Proc. APEC, 1998, pp. 679-685.

[17] D.P.Hohm and M.E.Ropp, "Comparative Study of Maximum Power Point Tracking Algorithms Using an Experimental, Programmable, Maximum Power Point Tracking", Test Bed, Proc. Photovoltaic Specialist Conference, 2000, pp. 1699-1702.

[18] K.H.Hussein, I.Muta, T.Hoshino and M.osakada "Maximum Power Point Tracking: an Algorithm for Rapidly Chancing Atmospheric Conditions", IEE Proc.-Gener. Transm. Distrib., vol. 142, no.1, pp. 59-64, January, 1995.

[19] K.K. Tse, B.M.T. Ho, H.S.-H. Chung, S.Y.R. Hui, "A comparative study of maximum-power-point trackers for photovoltaic panels using switching-frequency modulation scheme", IEEE Trans. on Industrial Electronics, vol. 51, no.2, pp. 410- 418, April 2004.

[20] R. Faranda S. Leva and V. Maugeri "MPPT techniques for PV Systems: energetic and cost omparison",IEEE lectrical Engineering Department of Politecnico di Milano, Piazza Leonardo da Vinci 32, 20133, Milano, Italy.2008.

[21] Anuradha Kar, Asim Kar "A New Maximum Power Point Tracking Algorithm for PV Modules under Partial Shading and Rapidly Varying Illumination”, IEEE Trans, University of Calcutta, Kolkata, India, 2009.

[22] Joanne Hui, Alireza Bakhshai, and Praveen K. Jain "A Hybrid Wind-Solar Energy System: A New Rectifier Stage Topology", IEEE Trans, Department of Electrical and Computer Engineering Queen's Center for Energy and Power Electronics Research (ePOWER), Queen's University,2010.

[23] J. Lu, S. Stegen, and D. Butler "High Frequency and High Power Density Transformers for DC/DC Converter used in Solar PV System" IEEE School of Engineering, Griffith University, Nathan, Brisbane, Qld 4111, Australia Surtek Pty Ltd, Acacia Ridge, Brisbane, Qld 4110, Australia,2008.

\section{BIOGRAPHIES:}

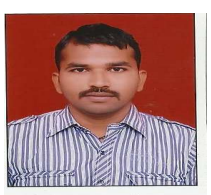

AMARNATH KURELLA: II-M.tech at Sri Venkateshwara Engineering College ,Suryapet his interested in Power Electronics,Power systems and non conventional energy sysems

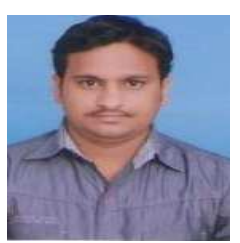

R SURESH: Working as a Assistant Professor at Sri Venkateshwara Engineering College ,Suryapet his interested in Power Electronics, Power Systems and non conventional energy sysems 